\title{
Tyrosine kinase inhibitors relax pulmonary arteries in human and murine precision-cut lung slices
}

Annette D. Rieg ${ }^{1 *}$ (D, Nina A. Bünting ${ }^{2}$, Christian Cranen², Said Suleiman², Jan W. Spillner ${ }^{3}$, Heike Schnöring ${ }^{3}$, Thomas Schröder ${ }^{4}$, Saskia von Stillfried ${ }^{5}$, Till Braunschweig ${ }^{5}$, Paul W. Manley ${ }^{6}$, Gereon Schälte ${ }^{1}$, Rolf Rossaint ${ }^{1}$, Stefan Uhlig ${ }^{2}$ and Christian Martin ${ }^{2}$

\begin{abstract}
Background: Tyrosine kinase inhibitors (TKIs) inhibit the platelet derived growth factor receptor (PDGFR) and gain increasing significance in the therapy of proliferative diseases, e.g. pulmonary arterial hypertension (PAH). Moreover, TKls relax pulmonary vessels of rats and guinea pigs. So far, it is unknown, whether TKls exert relaxation in human and murine pulmonary vessels. Thus, we studied the effects of TKls and the PDGFR-agonist PDGF-BB in precision-cut lung slices (PCLS) from both species.

Methods: The vascular effects of imatinib (mice/human) or nilotinib (human) were studied in Endothelin-1 (ET-1) preconstricted pulmonary arteries (PAs) or veins (PVs) by videomicroscopy. Baseline initial vessel area (IVA) was defined as $100 \%$. With regard to TKl-induced relaxation, $\mathrm{K}^{+}$-channel activation was studied in human PAs (PCLS) and imatinib/ nilotinib-related changes of CAMP and CGMP were analysed in human PAs/PVs (ELISA). Finally, the contractile potency of PDGF-BB was explored in PCLS (mice/human).

Results: Murine PCLS: Imatinib (10 HM) relaxed ET-1-pre-constricted PAs to 167\% of IVA. Vice versa, 100 nM PDGF-BB contracted PAs to $60 \%$ of IVA and pre-treatment with imatinib or amlodipine prevented PDGF-BB-induced contraction. Murine PVs reacted only slightly to imatinib or PDGF-BB. Human PCLS: $100 \mu \mathrm{M}$ imatinib or nilotinib relaxed ET-1-preconstricted PAs to $166 \%$ or $145 \%$ of IVA, respectively, due to the activation of $\mathrm{K}_{\mathrm{ATP}}{ }^{-}, \mathrm{BK}_{\mathrm{Ca}}{ }^{2+}$ - or $\mathrm{K}_{\mathrm{v}}$-channels. In PVs, imatinib exerted only slight relaxation and nilotinib had no effect. Imatinib and nilotinib increased CAMP in human PAs, but not in PVs. In addition, PDGF-BB contracted human PAs/PVs, which was prevented by imatinib.

Conclusions: TKIs relax pre-constricted PAs/PVs from both, mice and humans. In human PAs, the activation of $\mathrm{K}^{+}$channels and the generation of cAMP are relevant for TKI-induced relaxation. Vice versa, PDGF-BB contracts PAs/PVs (human/mice) due to PDGFR. In murine PAs, PDGF-BB-induced contraction depends on intracellular calcium. So, PDGFR regulates the tone of PAs/PVs. Since TKIs combine relaxant and antiproliferative effects, they may be promising in therapy of PAH.
\end{abstract}

Keywords: Tyrosine kinase inhibitors, Imatinib, Nilotinib, Pulmonary arteries, Pulmonary arterial hypertension

\footnotetext{
* Correspondence: arieg@ukaachen.de

${ }^{1}$ Department of Anaesthesiology, Medical Faculty Aachen, RWTH-Aachen,

Aachen, Germany

Full list of author information is available at the end of the article
}

(c) The Author(s). 2019 Open Access This article is distributed under the terms of the Creative Commons Attribution 4.0 International License (http://creativecommons.org/licenses/by/4.0/), which permits unrestricted use, distribution, and reproduction in any medium, provided you give appropriate credit to the original author(s) and the source, provide a link to the Creative Commons license, and indicate if changes were made. The Creative Commons Public Domain Dedication waiver (http://creativecommons.org/publicdomain/zero/1.0/) applies to the data made available in this article, unless otherwise stated. 


\section{Background}

Pulmonary arterial hypertension (PAH) is characterised by increased pulmonary vascular tone and remodelling of all vessel layers, e.g. intima, media and adventitia of the pulmonary vascular bed $[1,2]$. So far, PAH goes along with high mortality strongly depending on the underlying risk factors and the WHO functional class [3]. According to this, the arrest of disease progress appears to be essential to extend life time. With this regard, antiproliferative agents are of high clinical impact in PAH [4]. Recently, tyrosine kinase inhibitors (TKIs) have been proven to attenuate or prevent the pulmonary vascular remodelling by its inhibitory action on the platelet-derived growth factor receptor (PDGFR) [5-14]. Beyond that, a few studies in rats $[15,16]$ and guinea pigs [17] have shown that the TKIs imatinib [1517], sorafenib [15] and nilotinib [15] exert considerable relaxation in pulmonary arteries (PAs) $[15,16]$ and veins (PVs) [17]. PDGFR-inhibition, as a new therapeutic approach in $\mathrm{PAH}$ appears to be even more convincing, as the PDGFR-agonist PDGF-BB mediates aside proliferation also contraction, assigning PDGFR a central role in disease progress $[5,14,18-20]$.

Thusfar, it is unclear whether TKI- or imatinib-induced relaxation represents a basic and widespread phenome, operable across all species, e.g. in mice or humans. Whereas the IMPRES study revealed remarkable imatinibrelated pulmonary haemodynamic benefits in advanced $\mathrm{PAH}$ [10], considerable side effects such as pleural effusions, QTc prolongation or subdural haematoma also were reported [10, 21]. Apart from that, some TKIs primarily dasatinib [22-25], but also bosutinib [23, 25], sorafenib [26] or ponatinib $[25,27]$ exert toxic effects on the pulmonary vascular bed and even worsen PAH. Therefore, it would be beneficial to identify alternative TKIs which target both, the pulmonary vascular tone and the remodelling without exerting pulmonary vascular toxicity $[25,26]$. Nilotinib might represent such an alternative TKI, as it has been shown to act antiproliferative in smooth muscle cells (SMCs) from human PAs [28] and to relax rat PAs [15]. Until now it has been unclear, whether nilotinib also relaxes the human pulmonary vascular bed.

To investigate these topics, we studied the relaxant effect of imatinib in precision-cut lung slices (PCLS) from mice and men and also evaluated the relaxant potential of nilotinib in human PCLS. We analysed, whether $\mathrm{K}^{+}$-channel activation contributes to the relaxant effect of imatinib/nilotinib, as it was shown for imatinib in PVs from guinea pigs [17]. Beyond that, we studied the influence of imatinib/nilotinib on intracellular cAMP/cGMP in human PAs/PVs. Last, we analysed the contractile effects of PDGF-BB in pulmonary vessels (mice/men) and evaluated, whether this contraction is preventable by imatinib $[17,20]$.
The investigation was performed by the use of PCLS, a well-established method [17, 29-32] that allows PAs, PVs and airways to be investigated within their natural tissue anatomy [33]. PCLS are designated by a further strength; they enable to perform interspecies comparison [30-32]. This aspect is of particular value, as human lung tissue is quite limited and thus, it often only serves as a "proof of principle". However, due to the known interspecies differences [32] and a possible relevance of TKI-induced relaxation for the management of PAH [13], we primarily performed our study in human PCLS.

\section{Methods}

\section{Animals and patients}

Female BALB/c mice $(20 \pm 3 \mathrm{~g})$ were obtained from Charles River (Sulzfeld, Germany). All animal studies were approved by the Landesamt für Natur, Umwelt und Verbraucherschutz Nordrhein-Westfalen (ID: 8.8751.05.20.10.245 and 84-02.04.2013A146) and performed after the Directive 2010/63/EU of the European Parliament. Human lung tissue was obtained from patients undergoing lobectomy due to cancer. The study was performed according to the Declaration of Helsinki and approved by the local ethics committee (EK 61/09). All patients gave written informed consent. After macroscopic inspection and palpation by a pathologist, tumor-free human tissue was obtained. None of the patients showed any sign of PAH (echocardiography, histology).

\section{PCLS}

Murine PCLS were prepared as described [29] including some modifications. After terminal anaesthesia and exsanguination, the trachea was cannulated, the diaphragm and the thorax cavity were opened, the PA was cannulated and the left ventricle was disclosed by an incision. Porcine skin gelatin (6\%) was instilled via the pulmonary arterial cannula to wash out the blood and to stabilise the pulmonary vascular bed. Then, the ventricular incision and PA cannula were closed to prevent leakage of the gelatin from the pulmonary vascular bed. Next, murine lungs were filled via the trachea with $1.5 \%$ low melting agarose. Human lungs [31] were filled via a main bronchus with $1.5 \%$ low melting agarose. To harden murine and human agarose-filled lungs, they were cooled with ice. Then, tissue cores (diameter $11 \mathrm{~mm}$ ) were prepared and cut into about $300 \mu \mathrm{M}$ thick slices with a Krumdieck tissue slicer (Alabama Research \& Development, Munford, AL, USA). PCLS were incubated at $37^{\circ} \mathrm{C}$ and repeated medium changes were performed to wash out the agarose.

\section{Identification of the vessels, histology}

PAs and PVs were discriminated by their anatomical landmarks; PAs are located adjacent to airways, while 
PVs lie aside. After termination of the experiments, PCLS from both species were stained with Elastica van Gieson (EVG) staining to confirm their arterial or venous assignment [31] (Fig. 1).

\section{Pre-constriction, pharmacological interventions, measurements, and videomicroscopy}

Vessels often only relax, if they are pre-constricted. Therefore, we pre-constricted murine and human PAs and PVs with Endothelin-1 (ET-1). Prior to the measurement, murine airways were cut by a scalpel, because intact airways strongly contract in response to ET-1 and possibly influence thereby the vessel tone of murine PAs/PVs indirectly due to their close proximity.

To achieve comparable degrees of pre-constriction, murine PAs/PVs (Fig. 2b, c) and human PAs (Fig. 3b, c) were incubated with $100 \mathrm{nM}$ ET-1, whereas humans PVs were incubated with $50 \mathrm{nM} \mathrm{ET-1} \mathrm{(Fig.} \mathrm{3b,} \mathrm{c).} \mathrm{These} \mathrm{con-}$ centrations of ET-1 produced stable contractions after 30 min (Figs. 2c and 3c). In addition, murine PVs were also pre-constricted with $1 \mu \mathrm{M}$ ET-1 (Fig. 2f) and human PVs were also pre-constricted with $20 \mathrm{nM}$ ET-1 (Fig. 3f) to challenge imatinib-induced relaxation. After preconstriction, PAs and PVs from mice (Fig. 2d-f) and humans (Fig. 3d-f and Fig. 4b, c) were exposed to increasing concentrations of imatinib or nilotinib and concentration-response curves were performed.

In humans PAs, the involvement of $\mathrm{K}^{+}$-channel-activation within imatinib- or nilotinib-induced relaxation was evaluated. Therefore, PCLS were pre-constricted with
ET-1 and additionally pre-treated with one of the following inhibitors: $\mathrm{K}_{\mathrm{ATP}}$-channel $(10 \mu \mathrm{M}$ glibenclamide); $\mathrm{BK}_{\mathrm{Ca}}{ }^{2+}$-channel (100 nM iberiotoxin); $\mathrm{K}_{\mathrm{v}}$-channel (5 mM 4-aminopyridine (4-AP)); subsequently, concentrationresponse curves with imatinib and nilotinib were performed. Changes of the initial vessel area (IVA) were quantified in \% and are reported as "Change [\% of IVA]". Hence, a vessel area $<100 \%$ indicates contraction and a vessel area $>100 \%$ indicates relaxation. To compare relaxation of pre-treated vessels, the vessel area was defined after pre-treatment again as $100 \%$. Concentrationresponse curves of the vasodilators were performed and the effects reported as "Change [\% of IVA]". In the graphs, all pre-treatments were indicated. The luminal area of PAs/PVs was monitored with a digital video camera (Leica Viscam 1280, Leica DFC 280). The images were analysed with Optimas 6.5 (Media Cybernetics, Bothell, WA).

\section{Cyclic AMP and cGMP enzyme immunoassay}

To analyse the role of cAMP/cGMP within imatinib-or nilotinib-induced relaxation, human $\mathrm{PAs} / \mathrm{PVs}$ were isolated from tissue cores guided by their anatomical landmarks. PAs/PVs were incubated in medium, treated with imatinib or nilotinib ( 1 and $100 \mu \mathrm{M})$ and after $1 / 2$ hour frozen in liquid nitrogen. Cyclic AMP/cGMP was quantified with ELISA-kits following the manufacturer's protocol. For stabilisation, all samples or standards were acetylated. To measure cAMP levels, all samples were diluted 1:2 with $0.1 \mathrm{M}$ HCL. The ELISA was evaluated at $405 \mathrm{nM}$ (GENIOS, Tecan, Switzerland).

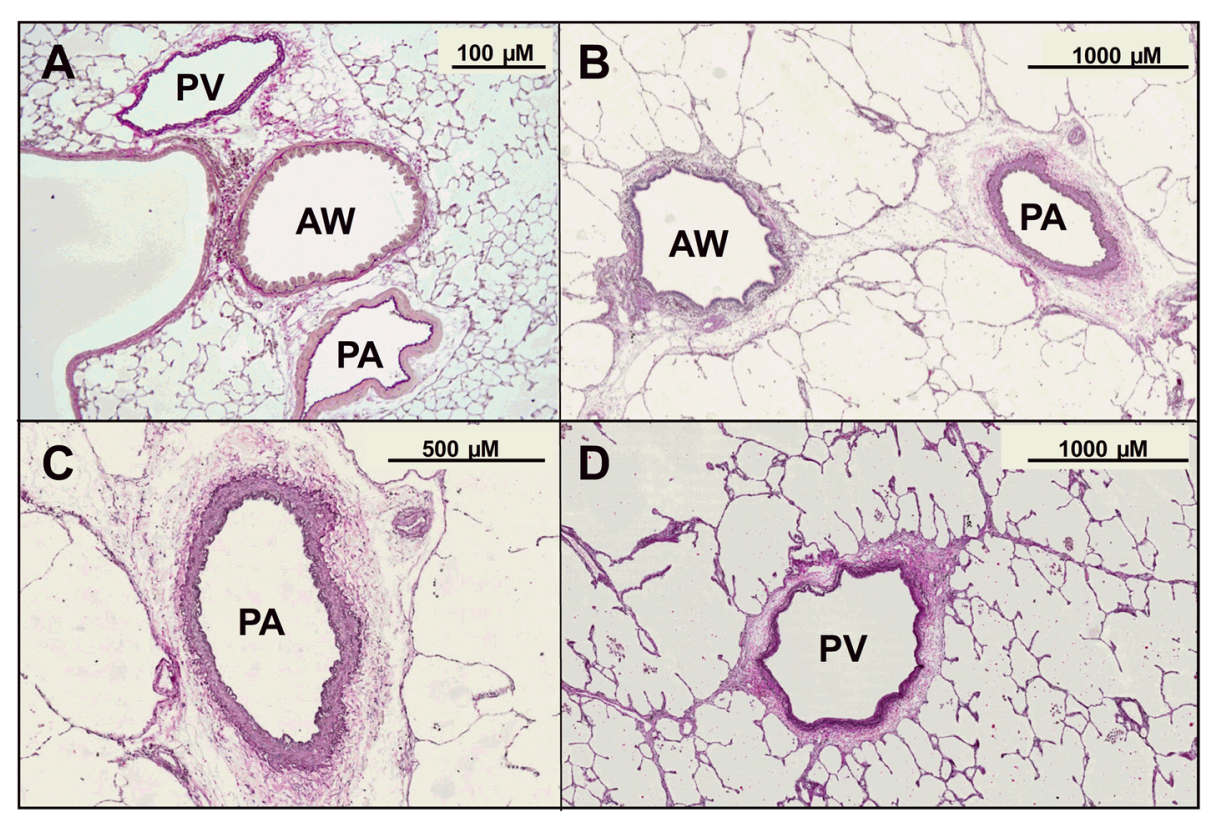

Fig. 1 Histology of murine and human PCLS. a Murine PCLS: The PA is located aside the airway (AW) and characterised by a thick media, whereas the PV lies more aside. b Human PCLS: The PA is located near the AW. c Human PCLS: PA with typical elastica interna and externa. d Human PCLS: PV with elastica interna 


\section{Murine PCLS}
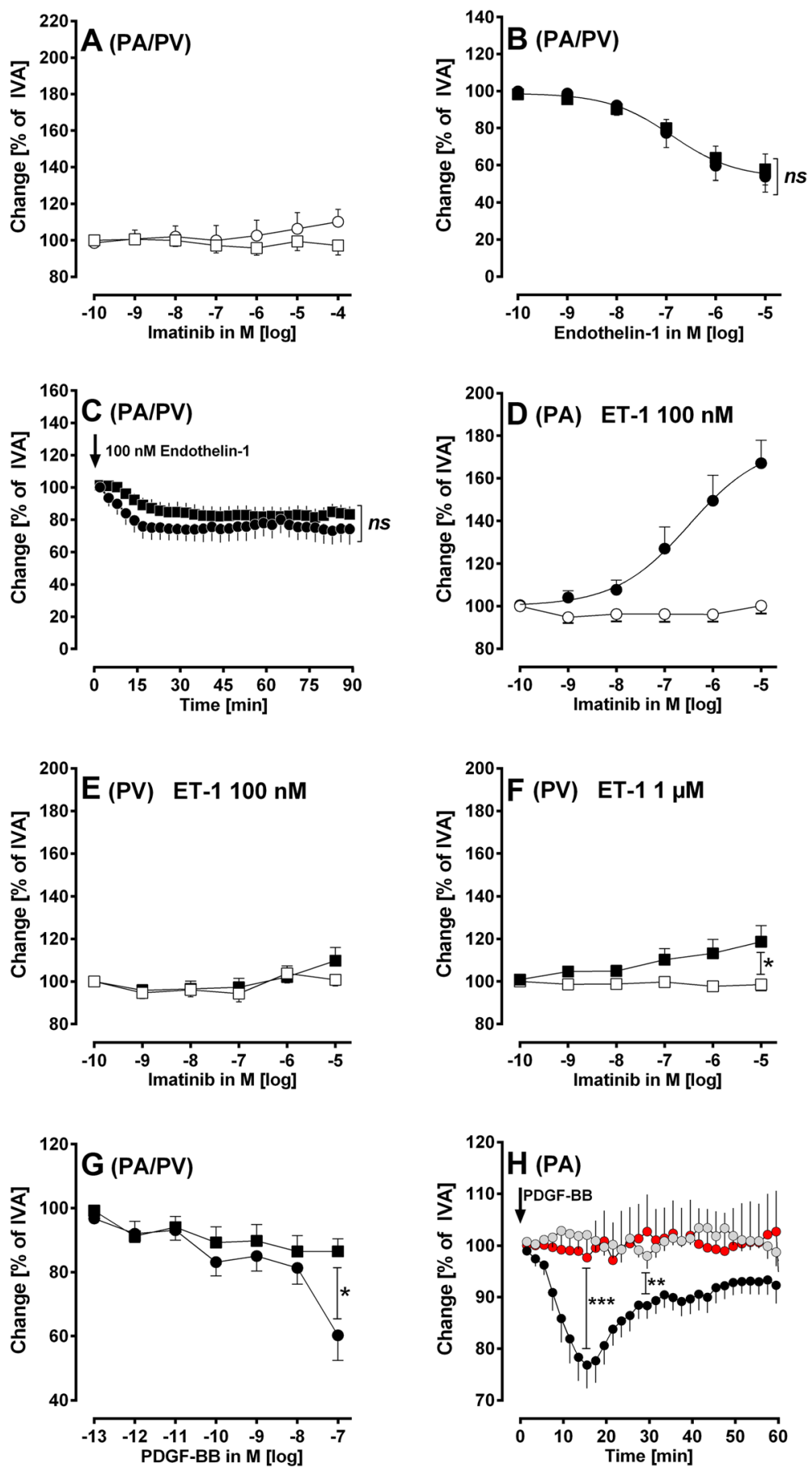

Fig. 2 (See legend on next page.) 
(See figure on previous page.)

Fig. 2 Murine PCLS. a Concentration-response curve of imatinib in naïve PAs and PVs: () PAs $(n=6)$; ( $)$ PVs $(n=7)$. b Concentration-response curve of ET-1 in naïve murine pulmonary vessels: $(\bullet)$ PA $(n=7) ;(\bullet)$ PV $(n=6)$. c The contractile effect of 100 nM ET-1 in PAs and PVs: $(\bullet)$ PA $(n=$ 4); ( $\mathbf{\bullet})$ PV $(n=5)$. d Effect of increasing concentrations of imatinib in pre-constricted PAs: () $100 \mathrm{nM} \mathrm{ET-1}(n=8) ;(\bullet) 100 \mathrm{nM}$ ET-1 / imatinib ( $n=10)$. e Effect of increasing concentrations of imatinib in pre-constricted PVs: ( $\square) 100 \mathrm{nM} \mathrm{ET-1}(n=8)$; (-) $100 \mathrm{nM}$ ET-1 / imatinib ( $n=10)$. f Effect of increasing concentrations of imatinib in pre-constricted PVs: ( $\square) 1 \mu \mathrm{M} \mathrm{ET-1}(n=7) ;(\mathbf{a}) 1 \mu \mathrm{M} \mathrm{ET-1} /$ imatinib $(n=9)$. g Concentration-response of PDGF-BB in murine PAs and PVs: $(\bullet)$ PA $(n=10) ;(\boldsymbol{\bullet})$ PV $(n=7)$. $\mathbf{h}$ The contractile effect of PDGF-BB in PAs: $(\bullet) 100 \mathrm{nM}$ PDGF-BB $(n=12) ;(\bigcirc) 1 \mu \mathrm{M}$ imatinib / 100 nM PDGF-BB ( $n=7)$; $(0) 100$ nM amlodipine / 100 nM PDGF-BB $(n=5)$. b, d EC 50 values were calculated using the standard 4-paramter logistic non-linear regression model. $\mathbf{c}, \mathbf{h}$ Statistics was performed by a linear mixed model analysis (LMM). $\mathbf{f}, \mathbf{g}$ Statistics was performed by the MannWhitney $U$ test. $P<0.05$ are considered as significant: ${ }^{*} p<0.05^{* *} p<0.01$ and ${ }^{* * *} p<0.001$

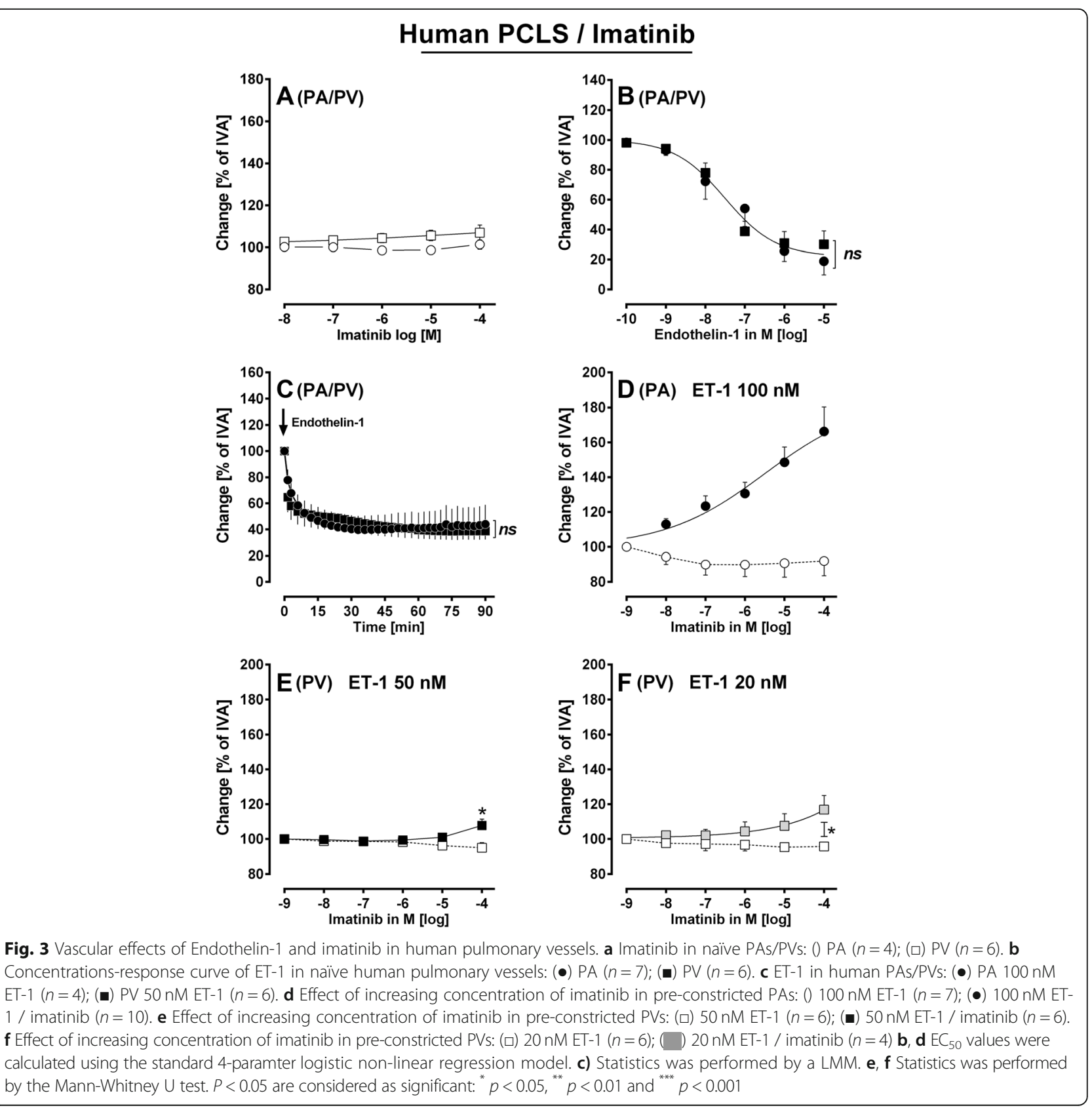




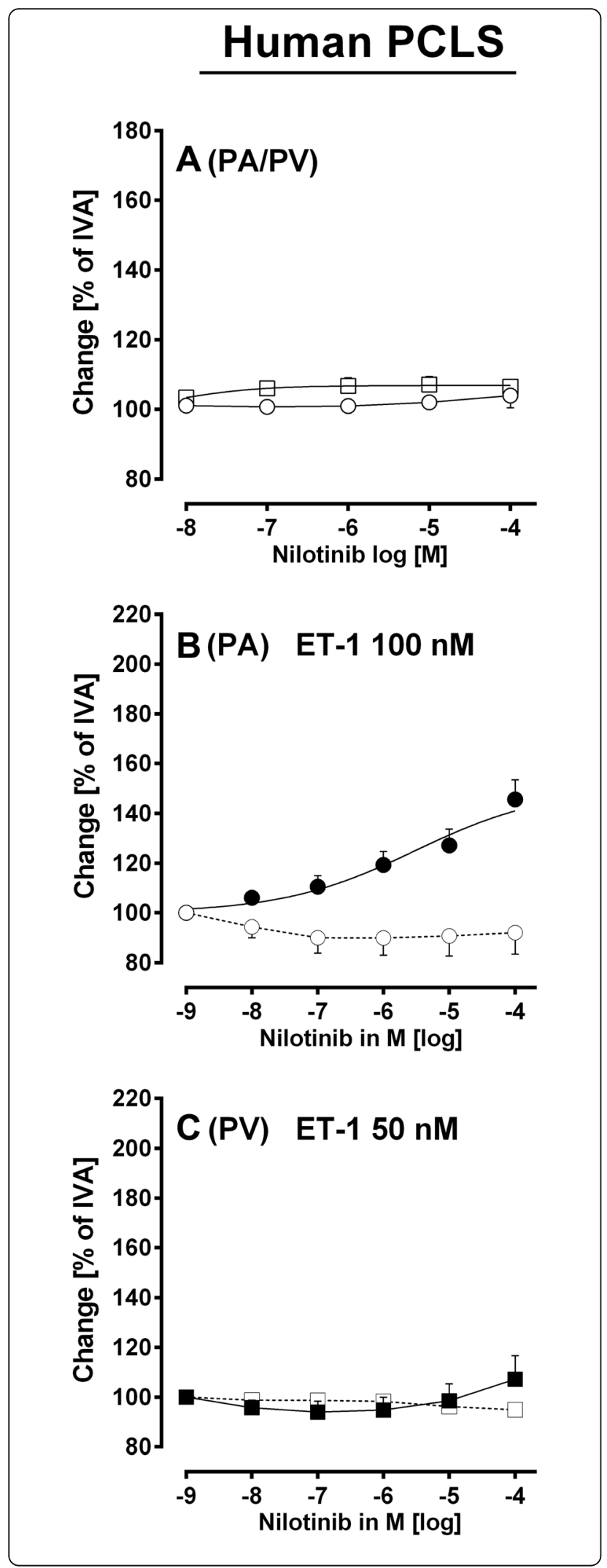

Fig. 4 Vascular effects of nilotinib in human pulmonary vessels. a Nilotinib in naïve PAs/PVs () PA $(n=5)$; ( $\square)$ PV $(n=6)$. b Effect of increasing concentration of nilotinib in pre-constricted PAs: () $100 \mathrm{nM} \mathrm{ET-1}(n=7)$; $(\bullet) 100 \mathrm{nM} \mathrm{ET-1} /$ imatinib $(n=10)$. c Effect of increasing concentration of nilotinib in pre-constricted PVs: ( $\square) 50 \mathrm{nM}$ ET-1 $(n=6)$; ( $\mathbf{a}) 50 \mathrm{nM} \mathrm{ET-1} /$ imatinib $(n=8)$. b $\mathrm{EC}_{50}$ value was calculated using the standard 4-paramter logistic nonlinear regression model. $P<0.05$ are considered as significant: ${ }^{*} p<$ $0.05,{ }^{* *} p<0.01$ and $^{* * *} p<0.001$

\section{Chemicals}

Pentobarbital (Narcoren) was purchased from Merial (Hallbergmoos, Germany), gelatin from porcine skin from Sigma-Aldrich and low melting point agarose from GERBU (Heidelberg, Germany). ET-1 was purchased from BIOTRENDS (Wangen, Switzerland). Glibenclamide, iberiotoxin, 4-aminopyridine and amlodipine were purchased from Tocris Bioscience (Ellisville, Missouri, USA). Human PDGF-BB was provided by Peprotech (Hamburg, Germany). Imatinib and nilotinib were kindly provided by Novartis (Basel, Switzerland). Standard laboratory chemicals were obtained from Sigma-Aldrich (Steinheim, Germany). The ELISA-kits were acquired from Enzo (Lörrach, Germany).

\section{Statistical analysis}

Statistical analysis was conducted using SAS software 9.3 (SAS Institute, Cary, North Carolina, USA) and GraphPad Prism 5.01 (GraphPad, La Jolla, USA). To analyse the data in Fig. 2b, d, Fig. 3b, d, Fig. 4b, Fig. 5b and Fig. 6a-c, EC F0 $_{50}$ values were calculated using the standard 4-parameter logistic non-linear regression model (GraphPad, La Jolla, USA). The AIC-criterion was used to select the most parsimonious model, i.e. a common bottom, top, slope and $\mathrm{EC}_{50}$ value in the regression model or the covariance matrix with the least number of parameters. Non-parametric analysis was performed by the Mann-Whitney U test; e.g. Figure 2f, g, Fig. 3e, f, Fig. 5d, e and Fig. 6d, e or by the Wilcoxon matched- pairs signed rank test (Fig. 2g) (GraphPad, La Jolla, USA). The data in Fig. 2c, h, Fig. 3c and Fig. 7a, b were analysed by a linear mixed model analysis (LMM) with the covariance structures $\mathrm{VC}$ or $\mathrm{AR}(1)$. The data in Fig. 5a-c and Fig. 6a-c were in part analysed by the LMM. P-values were adjusted for multiple comparisons by the false discovery rate and presented as mean \pm SEM; $(n)$ indicates the numbers of animals. $P<0.05$ was considered as significant.

\section{Results}

\section{Murine PCLS}

In naïve PAs and PVs, imatinib did not exert relaxation (Fig. 2a). To enhance the vessel tone, PAs and PVs were exposed to increasing concentrations of ET-1 (100 pM 


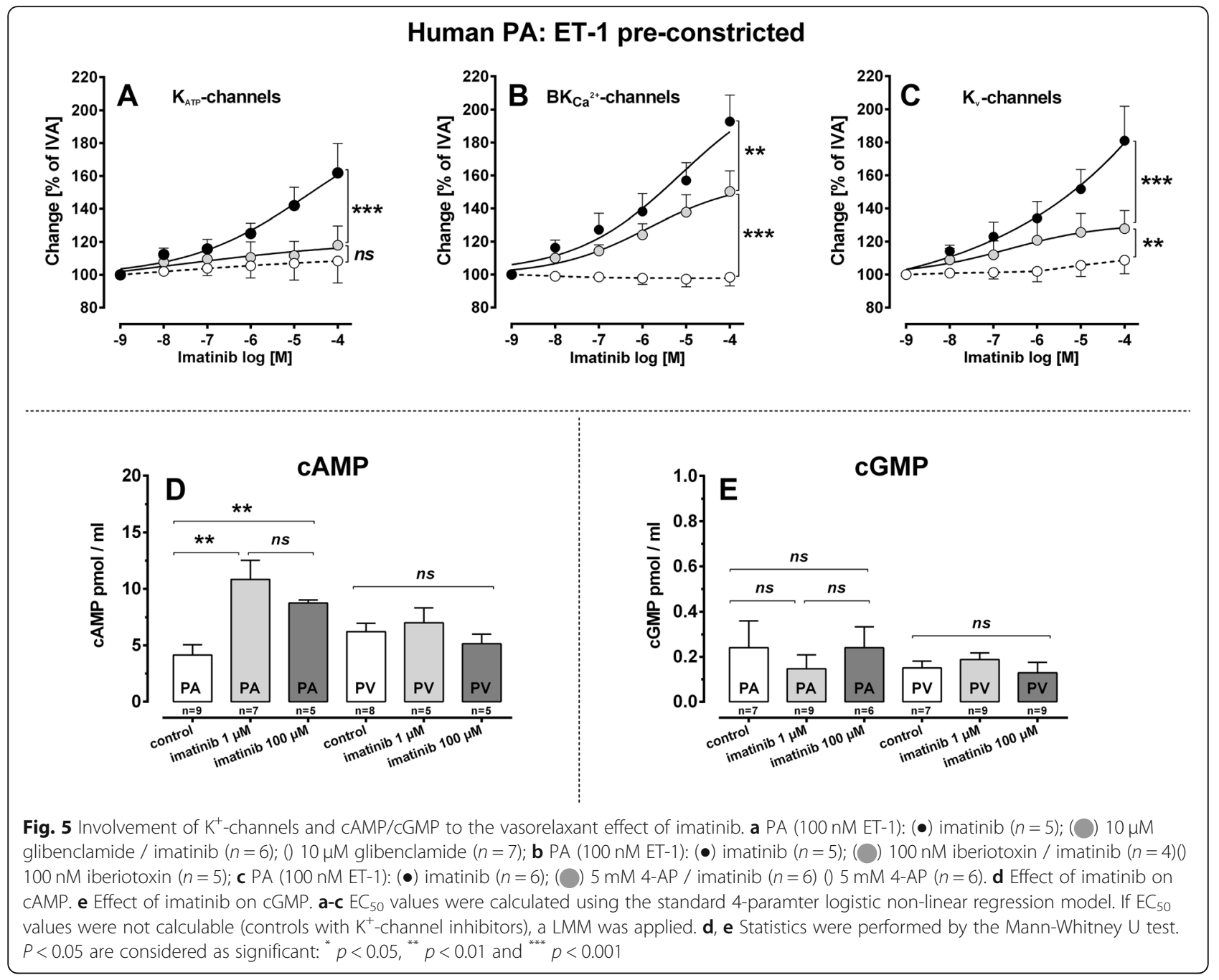

to $10 \mu \mathrm{M}$ ) which contracted PAs or PVs up to $54 \%$ or $57 \%$ of IVA, respectively (Fig. 2b). For both PAs and $\mathrm{PVs}$, the $-\operatorname{logEC} \mathrm{C}_{50}$ value was 6.8. PAs and PVs were exposed to $100 \mathrm{nM}$ ET-1 which contracted them comparably $(p>0.05)$ over $90 \mathrm{~min}$ (Fig. 2c). After preconstriction, imatinib relaxed PAs up to $167 \%$ of IVA with an $\mathrm{EC}_{50}$ value of $32 \mathrm{nM}$ (Fig. 2d), whereas pre-constricted PVs did not relax to imatinib (Fig. 2e). Next, we exposed murine PCLS to $1 \mu \mathrm{M}$ ET- 1 which contracted PAs and PVs to $52 \%$ or $75 \%$ of IVA, respectively (data not shown). Afterwards, $10 \mu \mathrm{M}$ imatinib slightly relaxed murine PVs up to $118 \%$ of IVA (Fig. 2f).

To study the effect of PDGF-BB in murine pulmonary vessel, they were treated with increasing concentrations of PDGF-BB $\left(10^{-13}-10^{-7} \mathrm{M}\right)$. PDGF-BB at $100 \mathrm{nM}$ contracted PAs up to $60 \%$ of IVA (Fig. 2g), whereas PVs only contracted to $86 \%$ of IVA (Fig. $2 \mathrm{~g}$ ). Next, PAs were exposed for $1 \mathrm{~h}$ to $100 \mathrm{nM}$ PDGF-BB which contracted them up to $76 \%$ of IVA with a maximum 15 min after application $(p<0.001)$. Afterwards the contractile effect of PDGF-BB decreased, e.g. to $89 \%$ of IVA $(p<0.01)$ at $30 \mathrm{~min}$ (Fig. 2h). Finally, PDGF-BB treated PAs remained slightly contracted (Fig. 2h), although without statistical significance $(p>0.05)$. In order to study whether PDGFBB-induced contraction is linked to PDGFR, we pretreated PAs with $1 \mu \mathrm{M}$ imatinib which prevented the contractile effect of PDGF-BB (Fig. 2h). Last we tried to find out, whether PDGF-BB-induced contraction depends on the activation of L-type $\mathrm{Ca}^{2+}$-channels and pre-treated PAs with $100 \mathrm{nM}$ amlodipine which also prevented the contractile effect of PDGF-BB (Fig. 2h).

\section{Human PCLS - the effects of imatinib and nilotinib Imatinib}

Next we investigated whether imatinib could relax human pulmonary vessels. Naïve PAs and PVs did not relax to imatinib (Fig. 3a). To pre-constrict PAs/PVs, they were exposed to increasing concentrations of ET-1 (Fig. 3b). PAs and PVs contracted comparably to ET-1 $(p>0.05)$; with a $-\operatorname{logEC} C_{50}$ of 7.5 for PAs and PVs (Fig. 3b). To 


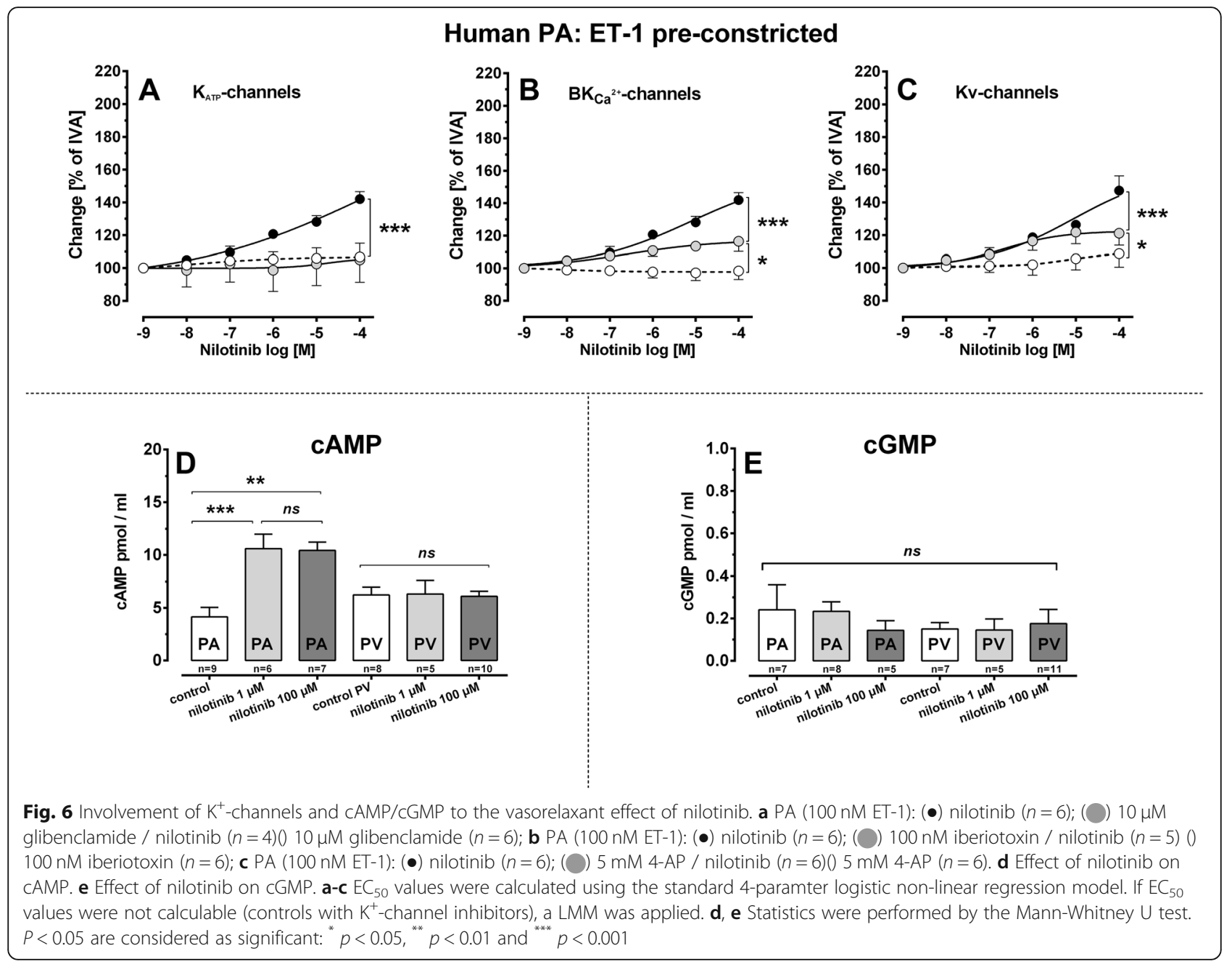

prevent a different degree of pre-constriction, we preconstricted PAs with $100 \mathrm{nM}$ ET-1 and PVs with $50 \mathrm{nM}$ ET-1 (Fig. 3c; $p>0.05$ ). After pre-constriction, imatinib relaxed PAs with $\mathrm{EC}_{50}$ values of $3.8 \mu \mathrm{M}$, e.g. 1 or $100 \mu \mathrm{M}$ imatinib relaxed PAs to $130 \%$ or $166 \%$ of IVA, respectively (Fig. 3d). For comparison, in oncological therapy, imatinib plasma levels of $1.8 \mu \mathrm{M}$ are reached [34, 35]. Further, humans PVs relaxed to $107 \%$ of IVA which was statistical different from control PVs $(p<0.05)$ (Fig. 3e). In order to exclude that pre-constriction was too strong in PVs and thus imatinib-induced relaxation masked; we preconstricted human PVs with $20 \mathrm{nM}$ ET-1. Afterwards, $100 \mu \mathrm{M}$ imatinib relaxed pre-constricted PVs to $116 \%$ of IVA $(p<0.05$; Fig. 3f).

\section{Nilotinib}

In consequence of our results with imatinib, we studied whether the TKI nilotinib also relaxes human pulmonary vessels. Nilotinib had no effect in naïve human PAs or PVs (Fig. 4a). However, if human PAs were pre-constricted with $100 \mathrm{nM}$ ET-1, they relaxed to increasing concentrations of nilotinib with $\mathrm{EC}_{50}$ values of $3 \mu \mathrm{M}$, e.g. PAs relaxed to $100 \mu \mathrm{M}$ nilotinib to $145 \%$ of IVA and to $1 \mu \mathrm{M}$ nilotinib to $119 \%$ of IVA (Fig. 4b). In humans, plasma levels of nilotinib of $0.7-5 \mu \mathrm{M}$ are reached [36]. Unlike imatinib, nilotinib did not relax pre-constricted PVs (Fig. 4c).

\section{Human lungs - intracellular signalling Imatinib: involvement of $K^{+}$-channels}

To study whether $\mathrm{K}^{+}$-channel-activation contributes to the relaxant effect of imatinib, we pre-treated human PAs with ET-1 and with one of the following $\mathrm{K}^{+}$-channel-inhibitors, e.g. $10 \mu \mathrm{g}$ glibenclamide for $\mathrm{K}_{\mathrm{ATP}}$-channels, $100 \mathrm{nM}$ iberiotoxin for $\mathrm{BK}_{\mathrm{Ca}}{ }^{2+}$-channels and $5 \mathrm{mM}$ 4-AP for $\mathrm{K}_{\mathrm{v}}$-channels (Fig. 5a-c). We did not perform these experiments in human PVs, as imatinib-induced relaxation was too weak. Simultaneous pre-treatment with ET-1 and glibenclamide, ET-1 and iberiotoxin or ET-1 and 5-AP did not alter the contractile effect of ET-1 in human PCLS (data not shown). However in 

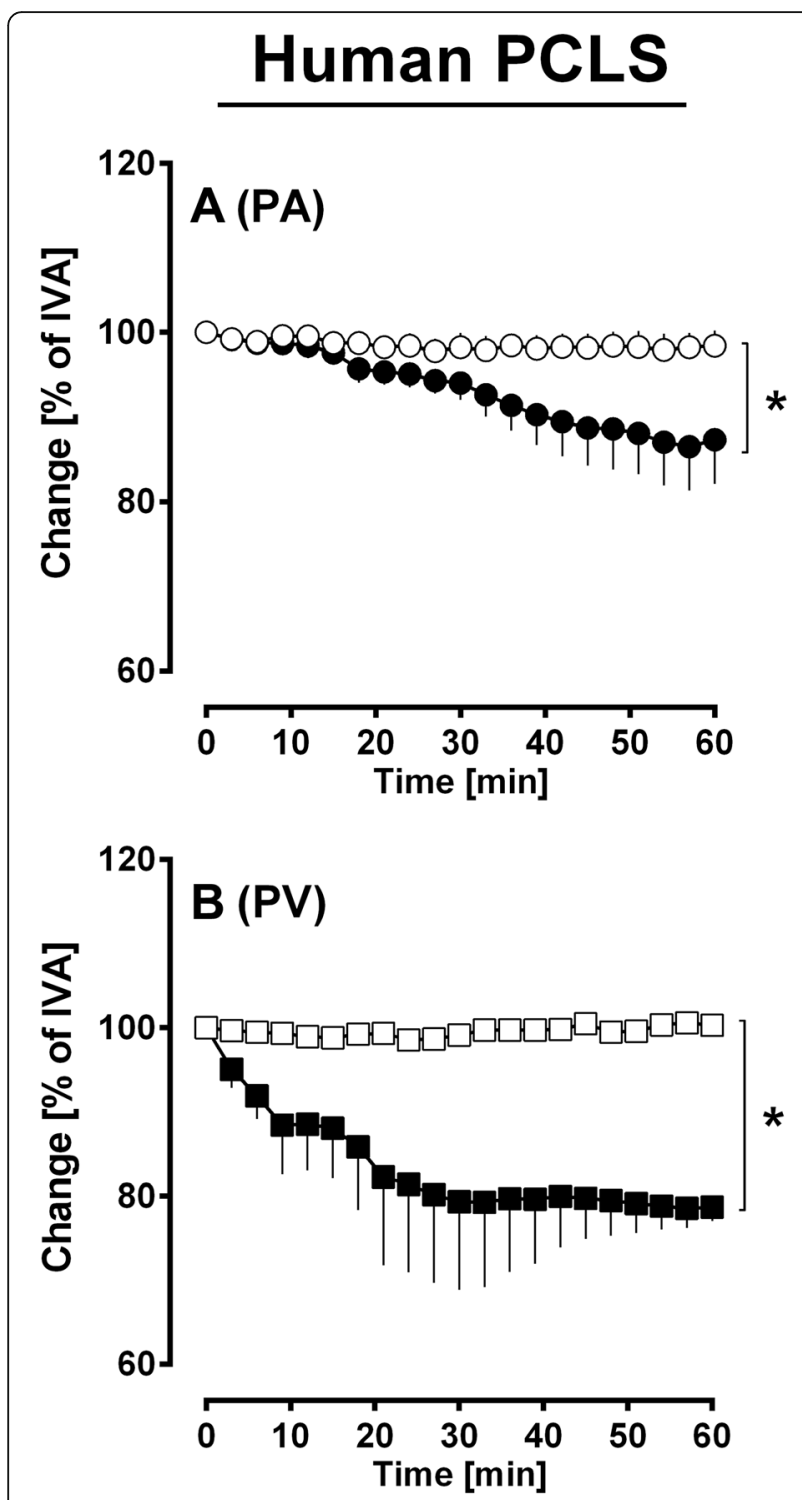

Fig. 7 The contractile effect of PDGF-BB in human PAs and PVs. a Human PAs: (•) $100 \mathrm{nM}$ PDGF-BB $(n=5) ;() 100 \mu \mathrm{M}$ imatinib / 100 nM PDGF-BB $(n=4)$. b Human PVs: (匹) 100 nM PDGF-BB $(n=4)$; ( $\square)$ $100 \mu \mathrm{M}$ imatinib / $100 \mathrm{nM}$ PDGF-BB $(n=3)$. a, b Statistics was performed by a LMM. $P<0.05$ are considered as significant: ${ }^{*} p<0.05$, ${ }^{* *} p<0.01$ and ${ }^{* * *} p<0.001$

human PAs, inhibition of $\mathrm{K}_{\mathrm{ATP}}$-channels (glibenclamide) nearly prevented the relaxant effect of imatinib (Fig. 5a; $p<0.0001)$. Inhibition of $\mathrm{BK}_{\mathrm{Ca}}{ }^{2+}$-channels (iberiotoxin) significantly reduced it $(p<0.01)$, as PAs relaxed to $150 \%$ of IVA in the presence of iberiotoxin compared to PAs with active $\mathrm{BK}_{\mathrm{Ca}}{ }^{2+}$-channels which relaxed to $192 \%$ of IVA (Fig. 5b). In addition, inhibition of $\mathrm{K}_{\mathrm{v}}$-channels (4-AP) also significantly reduced imatinib-induced relaxation $(p<0.01)$ and PAs only relaxed to $127 \%$ of IVA compared to $181 \%$ of IVA, if $\mathrm{K}_{\mathrm{v}}$-channels were active (Fig. 5c).
Thus, all three $\mathrm{K}^{+}$-channels mediate the relaxant effect of imatinib in human PAs, though $\mathrm{K}_{\mathrm{ATP}}$-channels seem to be dominant.

\section{Imatinib: involvement of CAMP/CGMP}

Next we investigated whether imatinib could induce the generation of vasorelaxant second messengers such as cAMP or cGMP. Thus, we treated isolated human PAs and PVs with 1 or $100 \mu \mathrm{M}$ imatinib (Fig. 5d, e). In human PAs, 1 or $100 \mu \mathrm{M}$ imatinib increased cAMP $(p<0.01)$, though no difference was found between both concentrations $(p>0.05)$, whereas imatinib did not increase cAMP in human PVs (Fig. 5d). In addition, imatinib did not increase cGMP in human PAs or PVs (Fig. 5e).

\section{Nilotinib: involvement of $\mathrm{K}^{+}$-channels}

Accordingly to imatinib, we pre-treated human PAs with the $\mathrm{K}_{\mathrm{ATP}}$-channel inhibitor glibenclamide $(10 \mathrm{nM})$, with the $\mathrm{BK}_{\mathrm{Ca}}{ }^{2+}$-channel-inhibitor iberiotoxin $(100 \mathrm{nM})$ and with the $\mathrm{K}_{\mathrm{v}}$-channel-inhibitor 4-AP $(5 \mathrm{mM})$ in order to study the role of $\mathrm{K}^{+}$-channels within nilotinib-induced relaxation (Fig. 6a-c). Inhibition of $\mathrm{K}_{\mathrm{ATP}}$-channels (Fig. 6a) prevented the relaxant effect of nilotinib $(p<0.001)$ and inhibition of $\mathrm{BK}_{\mathrm{Ca}}{ }^{2+}$-channels (Fig. 6b) significantly reduced it $(p<0.001)$, as PAs only relaxed to $116 \%$ of IVA, an effect which differed $(p<0.05)$ from control PAs without nilotinib-treatment. Further, inhibition of $\mathrm{K}_{\mathrm{v}}$-channels (Fig. 6c) reduced the relaxant effect of nilotinib $(p<0.001)$ and human PA only relaxed to $121 \%$ of IVA. This effect still differed $(p<0.05)$ from non-nilotinib-treated control PAs.

\section{Nilotinib: involvement of CAMP/CGMP}

As with imatinib, we analysed whether nilotinib increases intracellular cAMP and cGMP (Fig. 6d, e). In PAs, pretreatment with nilotinib $(1$ or $100 \mu \mathrm{M})$ significantly increased cAMP $(p<0.01)$, but no effect was found in PVs (Fig. 6d). In addition, nilotinib did not increase cGMP in PAs/PVs (Fig. 6e).

\section{Human lungs - contractile effects of PDGF-BB in human PAs and PVs}

The antiproliferative properties of imatinib rely on PDGFR-inhibition. Next we studied whether imatinibinduced relaxation also depends on PDGFR or conversely, if PDGF-BB contracts human PAs and PVs and if this contraction is prevented by imatinib. Therefore, we exposed human PAs and PVs to $100 \mathrm{nM}$ PDGF-BB with or without imatinib-pre-treatment (Fig. 7a, b). PDGF-BB at $100 \mathrm{nM}$ contracted human PAs (Fig. 7a; $p=0.01$ ) and PVs (Fig. 7b; $p=0.04$ ) and this contraction was prevented by imatinib ( $p<0.05$ for both). 


\section{Discussion}

TKI targeting the PDGFR kinases represent an intriguing approach to treat $\mathrm{PAH}$, as they reverse the remodelling and improve pulmonary haemodynamics [5-7, 9-11, 16]. Beyond that, the antiproliferative aspects of TKIs appear to be promising in idiopathic pulmonary fibrosis $[37,38]$ or chronic asthma [39, 40]. The present study focused on the relaxant potential of TKIs, which was recently observed in PAs from rats $[15,16]$ and PVs from guinea pigs [17]. Here firstly, we report TKI-mediated relaxation of human and murine pulmonary vessel. Conversely, PDGF-BB contracted human and murine PAs/ PVs. In human PAs, imatinib/nilotinib-related relaxation largely depended on $\mathrm{K}_{\mathrm{ATP}^{-}}, \mathrm{BK}_{\mathrm{Ca}}{ }^{2+}$ - and $\mathrm{K}_{\mathrm{v}}$-channels. Last, imatinib/nilotinib increased cAMP which most probably contributes to their relaxant effect.

\section{The relaxant effect of imatinib and nilotinib}

After pre-constriction, $10 \mu \mathrm{M}$ imatinib relaxed murine PAs to $167 \%$ and human PAs to $148 \%$ of IVA. In human PAs, this effect was gradable to $166 \%$, if $100 \mu \mathrm{M}$ imatinib were applied. Finally, the relaxant effect of imatinib was most potent in murine PAs. In contrast, imatinib had only a weak relaxant effect in PVs of both species. Nilotinib $(100 \mu \mathrm{M})$ relaxed pre-constricted human PAs to 145\% of IVA; whereas pre-constricted PVs did not react. Our results suggest that 1) the relaxant effect of TKIs depends on the species, 2) the relaxant effect of TKIs varies within PAs or PVs and 3) there exist differences within the relaxant potential of imatinib or nilotinib.

\section{Role of the species and the studied pulmonary vascular segments (PAs/PVs)}

Here, the relaxant effect of imatinib varied across the species and along the pulmonary vascular bed. So, the impact of species, vessel size and anatomical affiliation is reconfirmed [31, 41-47]. We studied central murine PAs/PVs (diameter: 100-250 $\mu \mathrm{m}$ ) and more peripheral human PAs/PVs (diameter: 500-1000 $\mu \mathrm{m}$ ). This fact might account for the varying relaxant potential of imatinib in human and murine PAs/PVs, as in respect of the vessel size and the pulmonary vascular segment, PAs and PVs exert a certain $\mathrm{K}^{+}$-channel diversity [42]. The diversity of PAs and PVs is supported by their distinct behaviour to NO $[41,43]$, prostacyclin [44] or cardiotonic agents $[31,45,46]$.

\section{Role of pre-constriction within TKI-induced relaxation}

We studied pulmonary vessels of a non-disease model. To pre-constrict PAs/PVs and to imitate the overexpression of ET-1-receptors and ET-1 in PAH [48, 49], we pre-constricted PAs/PVs with ET-1. In murine PAs/PVs, pre-constriction with $100 \mathrm{nM}$ ET-1 contracted PAs and PVs comparably to 74 and $83 \%$ of IVA, respectively. In human PAs/PVs, 100 nM ET-1 contracted PAs to $44 \%$ of IVA and $50 \mathrm{nM}$ ET-1 contracted PVs to $38 \%$ of IVA, which was also comparable. Although, pre-constriction was much weaker in murine pulmonary vessel, we did not use higher concentrations of ET-1, except from some experiments (Fig. 2f), as $1 \mu \mathrm{M}$ ET-1 contracted murine PAs stronger than the corresponding PVs (data not shown). In general, ET-1-induced contraction strongly depends on the lot-number and on the age of the compound. Anyhow, murine PAs relaxed stronger than human PAs. The degree of pre-constriction certainly accounts for the potency of vasodilators. However, we cannot conclude that less or more pre-constriction is superior, e.g. human PVs pre-constricted with $20 \mathrm{nM}$ ET-1 relaxed stronger to imatinib than PVs preconstricted with $50 \mathrm{nM}$ ET-1. In contrast, murine PVs pre-constricted with $100 \mathrm{nM}$ relaxed less to imatinib than PVs pre-constricted with $1 \mu \mathrm{M}$ ET- 1 . In this view, it is interesting that even comparable pre-constriction of murine (Fig. 2c) or human PAs/PVs (Fig. 3c), respectively, resulted in diverse responses. Beyond preconstriction, other rationales such as $\mathrm{K}^{+}$-channel-density might account for the relaxant effects of imatinib in PAs/PVs [42, 50].

\section{TKI-induced relaxation in dependence of their pharmacological profile}

In human PAs, nilotinib relaxed with a weaker maximal effect than imatinib; e.g. $145 \%$ vs. $166 \%$ of IVA, respectively. Although, this difference is statistically not significant, it might be clinically relevant, as the consequential vascular resistance should vary. According to the Hagen-Poiseuille law, the flow resistance increases 16 fold, if the radius divides in half. Finally, the presented vascular effects of imatinib and nilotinib should be sufficient to be relevant for pulmonary vascular resistance.

The pharmacological properties of imatinib and nilotinib suggest that the relaxant potency of imatinib is superior. Firstly, both represent unselective PDGFRantagonists inhibiting PDGFR- $\alpha \beta$ with comparable $\mathrm{IC}_{50}$ values, e.g. $71 \mathrm{nM}$ for nilotinib and $72 \mathrm{nM}$ for imatinib [51]. However secondly, imatinib and nilotinib also inhibit the non-receptor tyrosine kinase c-Abl (ABL1) [52-54]. Within the several functions of c-Abl, the regulation of SMC-contraction by actin polymerisation is of high impact $[55,56]$, e.g. activation of $\mathrm{C}-\mathrm{Abl}$ is involved within the contractile effect of PDGF-BB, as inhibition of c-Abl strongly attenuated PDGF-BB-induced contraction [20]. Both, imatinib and nilotinib inhibit c-Abl [51]. However, imatinib was approved to show a stronger docking score for the human c-Abl kinase receptor [57]. Due to this item, a stronger relaxant potency of imatinib seems to be conceivable. 
Role of $\mathrm{K}^{+}$-channel activation in TKI-induced relaxation To highlight the mechanisms beyond imatinib/nilotinibinduced relaxation, we studied the role of $\mathrm{K}_{\mathrm{ATP}^{-}}, \mathrm{BK}_{\mathrm{Ca}}{ }^{2+}$ and $\mathrm{K}_{\mathrm{v}}$-channels. All of them are expressed in pulmonary vessels $[42,50]$. Their stimulation hyperpolarises the cell membrane resulting in the reduction of cytosolic $\mathrm{Ca}^{2+}$-influx [58] and myosin light chain kinase (MLCK) activation [59]. Finally, vascular SMCs relax [59]. In human PAs, inhibition of all three $\mathrm{K}^{+}$-channels attenuated the relaxant effect of imatinib/nilotinib. Inhibition of $\mathrm{K}_{\mathrm{ATP}}$-channels prevented it, whereas inhibition of $\mathrm{K}_{\mathrm{v}}$-channels strongly reduced it. Further, inhibition of $\mathrm{BK}_{\mathrm{Ca}}{ }^{2+}$-channels also decreased the relaxant effect of nilotinib/imatinib, anyway; human PAs still relaxed to a half-maximal response. The minor significance of $\mathrm{BK}_{\mathrm{Ca}}{ }^{2+}$-channels within imatinibinduced relaxation goes in line with results in PVs from guinea pigs [17]; the superior role of $\mathrm{K}_{\mathrm{ATP}}$-channels is supported by results from human prostatic SMCs [60, 61]. In contrast, results from Pankey et al. [16] did not reveal imatinib-related $\mathrm{K}^{+}$-channel-activation in the rat pulmonary arterial bed. Finally, this study shows that human PAs relax to imatinib/nilotinib due to the activation of $\mathrm{K}_{\mathrm{ATP}^{-}}, \mathrm{BK}_{\mathrm{Ca}}{ }^{2+}$ - and $\mathrm{K}_{\mathrm{v}}$-channels.

\section{Role of CAMP and cGMP within TKI-induced relaxation}

The tone of vascular SMCs is regulated by signalling cascades which finally modulate actin polymerisation and MLC-phosphorylation; e.g. by the increase of intracellular $\mathrm{Ca}^{2+}$-level or by $\mathrm{Ca}^{2+}$-sensitisation [62-64]. In this view, cAMP/cGMP plays a leading part. Cyclic AMP and its dependent protein kinase A (PKA) cause relaxation by $\mathrm{K}^{+}$-channel-stimulation. Further, cAMP acts in a $\mathrm{Ca}^{2+}$-desensitising manner: 1) cAMP blocks MLCK; 2) cAMP activates MLC-phosphatase (MLCP) [65]. Here, we showed that imatinib/nilotinib increases cAMP in human PAs; but not in PVs. This fact might explain in part the weak or missing relaxant effect of imatinib or nilotinib in human PVs, respectively. In a previous study in PVs [17], imatinib-induced relaxation also only depended on cAMP [17].

MLCP is activated by the cGMP-dependent protein kinase G (PKG) [65]. In addition, PKG also activates $\mathrm{K}^{+}$channels [65]. Here, imatinib/nilotinib failed to increase cGMP in human PAs/PVs. This is in line with a previous study in PVs from guinea pigs [17], where imatinib 1) had no effects on cGMP-levels and 2) inhibition of NO-synthesis or PKG did not attenuate imatinib-induced relaxation. For nilotinib, no further data exist. Regarding imatinib, our results are supported by other studies $[15,16]$. However, opposing data also exist, e.g. imatinib relaxed SMCs from human corpus cavernosum [60] and prostatic SMCs [61] in dependence to NO. In summary, the role of cGMP within imatinib-induced relaxation appears to depend on the tissue from which SMCs derive.

\section{The contractile effect of PDGF-BB in human and murine PAs/PVs}

Corresponding to the relaxant effect of imatinib/nilotinib, PDGF-BB contracted pulmonary vessel from both species. Conversely, this effect was prevented by $100 \mu \mathrm{M}$ imatinib. Finally, PDGFR regulates the tone of human and murine pulmonary vessels which is in line with a former study in PVs from guinea pigs [17]. In murine PAs, the contractile effect of PDGF-BB depends on calcium. The role of calcium for PDGF-BB-induced contraction is supported by studies in systemic vessels; e.g. rabbit isolated ear arteries [66] or rat aorta $[67,68]$ and pulmonary vessels; e.g. PVs from guinea pigs [20]. The contractile effect of PDGF-BB was comparable in human PAs and PVs (Fig. 7a, b; $p>0.05$ ), although a trend towards a stronger effect in human PVs appears to be evident. This notice is somewhat unexpected, as imatinib-induced relaxation was weaker in PVs. In this view, unspecific mechanisms not related to PDGFRactivation are less probable, as imatinib prevented PDGFBB-induced contraction. Other considerations include the activation of $\mathrm{C}-\mathrm{Abl}$, as it was shown for PVs [20]. In this regard, a varying activation of $\mathrm{c}-\mathrm{Abl}$ in human PAs and PVs is conceivable, leading to a different degree of contraction.

\section{Conclusion}

In conclusion, TKIs relax human and murine pulmonary vessels. Imatinib and nilotinib efficaciously relax human PAs by $\mathrm{K}_{\mathrm{ATP}^{-}}, \mathrm{BK}_{\mathrm{Ca}}{ }^{2+}$ - and $\mathrm{K}_{\mathrm{v}}$-channel-activation. Here, $1 \mu \mathrm{M}$ imatinib relaxed human PAs to $130 \%$ of IVA and $1 \mu \mathrm{M}$ nilotinib relaxed human PAs to $119 \%$ of IVA. For comparison, during cancer therapy, imatinib [34, 35] and nilotinib [36] reach plasma levels of $1.8 \mu \mathrm{M}$ and $0.7-5 \mu \mathrm{M}$, respectively. Hence, their relaxant effects appear to be of clinical relevance in the human pulmonary arterial bed and might be also of impact in $\mathrm{PAH}$. With regard to imatinib-related side effects $[10,21]$, it is of clinical impact that nilotinib also relaxes human PAs and that TKIs also exert a relaxant effect via inhalation [17]. Anyhow, TKIinduced relaxation appears to be a class phenomenon which has been proven for several TKIs e.g. imatinib, nilotinib, sorafenib SU6668, DMPQ [15-17]. It includes with sorafenib also a TKI which exerts pulmonary vascular toxicity, whereas dasatinib was not shown to relax PAs and PVs. In view of PDGF-BB, we showed that PDGFR determines the tone of human and murine $\mathrm{PA} / \mathrm{PV}$ and that this is preventable by imatinib. So, aside the antiproliferative effect of TKIs 
[5-14], this study confirms pulmonary vascular relaxation by PDGFR-antagonism. Recently, this dual action of PDGFR-antagonism was also shown in rats' systemic vessels $[16,69]$. In summary, TKIs are promising agents in $\mathrm{PAH}$ and other diseases with underlying proliferative and contractile pathophysiology.

\section{Abbreviation}

4-AP: 4-aminopyridine; ET-1: Endothelin-1; IVA: Initial vessel area; LMM: Linear mixed model analysis; MLCK: Myosin light chain kinase; MLCP: MLCphosphatase; PA: Pulmonary artery; PAH: Pulmonary arterial hypertension; PCLS: Precision-cut lung slice; PDGFR: Platelet-derived growth factor receptor; PKA: Protein kinase A; PKG: Protein kinase G; PV: Pulmonary vein; SMC: Smooth muscle cell; TKI: Tyrosine kinase inhibitor

\section{Acknowledgements}

This project was supported by the START programme of the RWTH Aachen. We further gratefully acknowledge Hanna Czajkowska and Nadine Ruske for excellent technical assistance, as well as Novartis, Switzerland for providing imatinib and nilotinib.

\section{Authors' contributions}

ADR designed the study, performed the experiments, analysed the data, interpreted the data and wrote the manuscript. NAB performed the experiments, analysed the data and interpreted the data. CC performed the experiments, analysed the data and interpreted the data. SS performed the experiments, analysed the data and interpreted the data. JWS helped with the human lung tissue and critically reviewed the manuscript. HS helped with the human lung tissue and critically reviewed the manuscript. TS helped with the human lung tissue and critically reviewed the manuscript. SvS helped with the human lung tissue and critically reviewed the manuscript. TB helped with the human lung tissue and critically reviewed the manuscript. PWM analysed the data, interpreted the data and critically reviewed the manuscript. GS analysed the data, interpreted the data, helped with the human lung tissue and critically reviewed the manuscript. RR analysed the data, interpreted the data and critically reviewed the manuscript. SU analysed the data, interpreted the data and critically reviewed the manuscript. CM designed the study, analysed the data, interpreted the data and critically reviewed the manuscript. All authors read and approved the final manuscript.

\section{Funding}

This work was funded by the START program (grant 109/14; 691440) of the RWTH-Aachen. The funders had no influence of the study design, data collection and analysis, decision to publish or preparation of the manuscript

\section{Availability of data and materials}

The datasets generated and analysed during the current study are available from the corresponding author on reasonable request.

\section{Ethics approval and consent to participate}

Female BALB/c mice $(20 \pm 3 \mathrm{~g})$ were obtained from Charles River (Sulzfeld, Germany). All animal studies were approved by the Landesamt für Natur, Umwelt und Verbraucherschutz Nordrhein-Westfalen (ID: 8.87-51.05.20.10.245 and 84-02.04.2013A146) and performed after the Directive 2010/63/EU of the European Parliament. Human lung tissue was obtained from patients undergoing lobectomy due to cancer. The study was performed according to the Declaration of Helsinki and approved by the local ethics committee (EK 61/09). All patients gave written informed consent.

\section{Consent for publication}

Not applicable.

\section{Competing interests}

The authors declare that they have no competing interests.

\section{Author details}

'Department of Anaesthesiology, Medical Faculty Aachen, RWTH-Aachen, Aachen, Germany. ${ }^{2}$ Institute of Pharmacology and Toxicology, Medical Faculty Aachen, RWTH-Aachen, Aachen, Germany. ${ }^{3}$ Department of Cardiac and Thoracic Surgery, Medical Faculty Aachen, RWTH-Aachen, Aachen,
Germany. ${ }^{4}$ Department of Surgery, Luisenhospital Aachen, Aachen, Germany. ${ }^{5}$ Institute of Pathology, Medical Faculty Aachen, RWTH-Aachen, Aachen, Germany. ${ }^{6}$ Novartis Pharma AG, Basel, Switzerland.

Received: 20 October 2018 Accepted: 16 May 2019

Published online: 06 June 2019

\section{References}

1. Tuder RM, Abman SH, Braun T, Capron F, Stevens T, Thistlethwaite PA Haworth SG (2009) Development and pathology of pulmonary hypertension. J am Coll Cardiol 54: S3-S9. S0735-1097(09)01212-1 [doi]; https://doi.org/10.1016/j.jacc.2009.04.009.

2. Tuder RM, Archer SL, Dorfmuller P, Erzurum SC, Guignabert C, Michelakis E, Rabinovitch M, Schermuly R, Stenmark KR, Morrell NW (2013) Relevant issues in the pathology and pathobiology of pulmonary hypertension. $\mathrm{J}$ am Coll Cardiol. 62: D4-12. S0735-1097(13)05868-3 ;https://doi.org/10.1016/j.jacc. 2013.10.025 [doi].

3. Hoeper MM, Kramer T, Pan Z, Eichstaedt CA, Spiesshoefer J, Benjamin N, Olsson KM, Meyer K, Vizza CD, Vonk-Noordegraaf A, Distler O, Opitz C, Gibbs JSR, Delcroix M, Ghofrani HA, Huscher D, Pittrow D, Rosenkranz S, Grunig E. Mortality in pulmonary arterial hypertension: prediction by the 2015 European pulmonary hypertension guidelines risk stratification model. Eur Respir J. 2017:50. https://doi.org/10.1183/13993003.00740-2017.

4. Pullamsetti SS, Schermuly R, Ghofrani A, Weissmann N, Grimminger F, Seeger W. Novel and emerging therapies for pulmonary hypertension. Am J Respir Crit Care Med. 2014;189:394-400. https://doi.org/10.1164/rccm. 201308-1543PP

5. Berghausen $\mathrm{E}$, Ten FH, Rosenkranz S. Targeting of platelet-derived growth factor signaling in pulmonary arterial hypertension. Handb Exp Pharmacol. 2013;218:381-408. https://doi.org/10.1007/978-3-642-38664-0_16.

6. Ciuclan LI, Hussey M, Duggan N, Burton VJ, Good R, Beach S, Jones P, Fox R, Konstantinova I, Bonneau O, Rowlands D, Pearce A, MacLean MR, Jarai G, Westwick J, Thomas M. Imatinib attenuates hypoxia-induced PAH pathology via reduction in serotonin through inhibition of tryptophan hydroxylase 1 expression. San Francisco: Abstract, ATS; 2012.

7. Ghofrani HA, Seeger W, Grimminger F. Imatinib for the treatment of pulmonary arterial hypertension. N Engl J Med. 2005;353:1412-3. https://doi. org/10.1056/NEJMc051946

8. Ghofrani HA, Morrell NW, Hoeper MM, Olschewski H, Peacock AJ, Barst RJ Shapiro S, Golpon H, Toshner M, Grimminger F, Pascoe S. Imatinib in pulmonary arterial hypertension patients with inadequate response to established therapy. Am J Respir Crit Care Med. 2010;182:1171-7. https://doi. org/10.1164/rccm.201001-01230C.

9. Grimminger F, Schermuly RT. PDGF receptor and its antagonists: role in treatment of PAH. Adv Exp Med Biol. 2010;661:435-46. https://doi.org/10. 1007/978-1-60761-500-2_28.

10. Hoeper MM, Barst RJ, Bourge RC, Feldman J, Frost AE, Galie N, GomezSanchez MA, Grimminger F, Grunig E, Hassoun PM, Morrell NW, Peacock AJ, Satoh T, Simonneau G, Tapson VF, Torres F, Lawrence D, Quinn DA, Ghofrani HA. Imatinib mesylate as add-on therapy for pulmonary arterial hypertension: results of the randomized IMPRES study. Circulation. 2013;127: 1128-38. https://doi.org/10.1161/CIRCULATIONAHA.112.000765.

11. Klein M, Schermuly RT, Ellinghaus P, Milting H, Riedl B, Nikolova S, Pullamsetti SS, Weissmann N, Dony E, Savai R, Ghofrani HA, Grimminger F, Busch AE, Schafer S. Combined tyrosine and serine/threonine kinase inhibition by sorafenib prevents progression of experimental pulmonary hypertension and myocardial remodeling. Circulation. 2008;118:2081-90. https://doi.org/10.1161/CIRCULATIONAHA.108.779751.

12. Schermuly RT, Dony E, Ghofrani HA, Pullamsetti S, Savai R, Roth M, Sydykov A, Lai YJ, Weissmann N, Seeger W, Grimminger F. Reversal of experimental pulmonary hypertension by PDGF inhibition. J Clin Invest. 2005;115:2811-21. https://doi.org/10.1172/JCI24838.

13. Ten FH, Dumitrescu D, Berghausen E, Vantler M, Caglayan E, Rosenkranz S. Imatinib mesylate for the treatment of pulmonary arterial hypertension. Expert Opin Investig Drugs. 2012;21:119-34. https://doi.org/10.1517/ 13543784.2012.632408

14. Zhang L, Ma J, Shen T, Wang S, Ma C, Liu Y, Ran Y, Wang L, Liu L, Zhu D. Platelet-derived growth factor (PDGF) induces pulmonary vascular remodeling through 15-LO/15-HETE pathway under hypoxic condition. Cell Signal. 2012;24:1931-9. https://doi.org/10.1016/j.cellsig.2012.06.007. 
15. Abe K, Toba M, Alzoubi A, Koubsky K, Ito M, Ota H, Gairhe S, Gerthoffer WT, Fagan KA, McMurtry IF, Oka M. Tyrosine kinase inhibitors are potent acute pulmonary vasodilators in rats. Am J Respir Cell Mol Biol. 2011;45:804-8. https://doi.org/10.1165/rcmb.2010-03710C.

16. Pankey EA, Thammasibon S, Lasker GF, Baber S, Lasky JA, Kadowitz PJ. Imatinib attenuates monocrotaline pulmonary hypertension and has potent vasodilator activity in the pulmonary and systemic vascular beds of the rat. Am J Physiol heart Circ Physiol. 2013;305:1288-96. https://doi.org/10.1152/ ajpheart.00329.2013.

17. Maihofer NA, Suleiman S, Dreymuller D, Manley PW, Rossaint R, Uhlig S, Martin C, Rieg AD. Imatinib relaxes the pulmonary venous bed of Guinea pigs. Respir Res. 2017;18:32. https://doi.org/10.1186/s12931-017-0514-0.

18. Andrae J, Gallini R, Betsholtz C. Role of platelet-derived growth factors in physiology and medicine. Genes Dev. 2008;22:1276-312. https://doi.org/10. 1101/gad.1653708.

19. Antoniu SA. Targeting PDGF pathway in pulmonary arterial hypertension. Expert Opin Ther targets. 2012;16:1055-63. https://doi.org/10.1517/ 14728222.2012.719500.

20. Rieg AD, Suleiman S, Anker C, Verjans E, Rossaint R, Uhlig S, Martin C. PDGF$\mathrm{BB}$ regulates the pulmonary vascular tone: impact of prostaglandins, calcium. Respir Res. 2018;19:120. https://doi.org/10.1186/s12931-018-0829-5.

21. Frost AE, Barst RJ, Hoeper MM, Chang HJ, Frantz RP, Fukumoto Y, Galie N, Hassoun PM, Klose H, Matsubara H, Morrell NW, Peacock AJ, Pfeifer M, Simonneau G, Tapson VF, Torres F, Dario VC, Lawrence D, Yang W, Felser JM, Quinn DA, Ghofrani HA. Long-term safety and efficacy of imatinib in pulmonary arterial hypertension. J Heart Lung Transplant. 2015;34:1366-75. https://doi.org/10.1016/j.healun.2015.05.025.

22. Guignabert C, Phan C, Seferian A, Huertas A, Tu L, Thuillet R, Sattler C, Le HM, Tamura Y, Jutant EM, Chaumais MC, Bouchet S, Maneglier B, Molimard M, Rousselot P, Sitbon O, Simonneau G, Montani D, Humbert M. Dasatinib induces lung vascular toxicity and predisposes to pulmonary hypertension. J Clin Invest. 2016;126:3207-18. https://doi.org/10.1172/JCl86249.

23. Riou M, Seferian A, Savale L, Chaumais MC, Guignabert C, Canuet M, Magro $P$, Rea $D$, Sitbon $O$, Jais $X$, Humbert M, Montani D. Deterioration of pulmonary hypertension and pleural effusion with bosutinib following dasatinib lung toxicity. Eur Respir J. 2016;48:1517-9. https://doi.org/10.1183/ 13993003.01410-2016.

24. Montani D, Bergot E, Gunther S, Savale L, Bergeron A, Bourdin A, Bouvaist $H$ Canuet M, Pison C, Macro M, Poubeau P, Girerd B, Natali D, Guignabert C, Perros F, O'Callaghan DS, Jais X, Tubert-Bitter P, Zalcman G, Sitbon O, Simonneau G, Humbert M. Pulmonary arterial hypertension in patients treated by dasatinib. Circulation. 2012;125:2128-37. https://doi.org/10.1161/ CIRCULATIONAHA.111.079921.

25. Weatherald J, Chaumais MC, Montani D. Pulmonary arterial hypertension induced by tyrosine kinase inhibitors. Curr Opin Pulm Med. 2017;23:392-7. https://doi.org/10.1097/MCP.0000000000000412.

26. Godinas L, Guignabert C, Seferian A, Perros F, Bergot E, Sibille Y, Humbert M, Montani D. Tyrosine kinase inhibitors in pulmonary arterial hypertension: a double-edge sword? Semin Respir Crit Care Med. 2013;34:714-24. https:// doi.org/10.1055/s-0033-1356494.

27. Quilot FM, Georges M, Favrolt N, Beltramo G, Foignot C, Grandvuillemin A, Montani D, Bonniaud P, Camus P. Pulmonary hypertension associated with ponatinib therapy. Eur Respir J. 2016;47:676-9. https://doi.org/10.1183/ 13993003.01110-2015.

28. Pullamsetti SS, Berghausen EM, Dabral S, Tretyn A, Butrous E, Savai R, Butrous G, Dahal BK, Brandes RP, Ghofrani HA, Weissmann N, Grimminger F, Seeger W, Rosenkranz S, Schermuly RT. Role of Src tyrosine kinases in experimental pulmonary hypertension. Arterioscler Thromb Vasc Biol. 2012; 32:1354-65. https://doi.org/10.1161/ATVBAHA.112.248500.

29. Held HD, Martin C, Uhlig S. Characterization of airway and vascular responses in murine lungs. Br J Pharmacol. 1999;126:1191-9. https://doi.org/ 10.1038/sj.bjp.0702394

30. Ressmeyer A, Larsson A, Vollmer E, Dahlen S, Uhlig S, Martin C. Characterisation of Guinea pig precision-cut lung slices: comparison with human tissues. Eur Respir J. 2006;28:603-11.

31. Rieg AD, Suleiman S, Perez-Bouza A, Braunschweig T, Spillner JW, Schroder T, Verjans E, Schalte G, Rossaint R, Uhlig S, Martin C. Milrinone relaxes pulmonary veins in Guinea pigs and humans. PLoS One. 2014;9:e87685. https://doi.org/10.1371/journal.pone.0087685.

32. Schleputz M, Rieg AD, Seehase S, Spillner J, Perez-Bouza A, Braunschweig T, Schroeder T, Bernau M, Lambermont V, Schlumbohm C, Sewald K,
Autschbach R, Braun A, Kramer BW, Uhlig S, Martin C. Neurally mediated airway constriction in human and other species: a comparative study using precision-cut lung slices (PCLS). PLoS One. 2012;7:e47344. https://doi.org/10. 1371/journal.pone.0047344 PONE-D-12-11366.

33. Sanderson MJ. Exploring lung physiology in health and disease with lung slices. Pulm Pharmacol Ther. 2011;24:452-65. S1094-5539(11)00107-6. https://doi.org/10.1016/j.pupt.2011.05.001.

34. Druker BJ, Talpaz M, Resta DJ, Peng B, Buchdunger E, Ford JM, Lydon NB, Kantarjian H, Capdeville R, Ohno-Jones S, Sawyers CL. Efficacy and safety of a specific inhibitor of the BCR-ABL tyrosine kinase in chronic myeloid leukemia. N Engl J Med. 2001;344:1031-7. https://doi.org/10.1056/ NEJM200104053441401.

35. Guilhot F, Hughes TP, Cortes J, Druker BJ, Baccarani M, Gathmann I, Hayes M, Granvil C, Wang Y. Plasma exposure of imatinib and its correlation with clinical response in the tyrosine kinase inhibitor optimization and selectivity trial. Haematologica. 2012;97:731-8. Haematol.2011.045666. https://doi.org/ 10.3324/haematol.2011.045666.

36. Boons CCLM, Chahbouni A, Schimmel AM, Wilhelm AJ, den Hartog YM, Janssen JJWM, Hendrikse NH, Hugtenburg JG, Swart EL. Dried blood spot sampling of nilotinib in patients with chronic myeloid leukaemia: a comparison with venous blood sampling. J Pharm Pharmacol. 2017;69: 1265-74. https://doi.org/10.1111/jphp.12757.

37. Richeldi L, du Bois RM, Raghu G, Azuma A, Brown KK, Costabel U, Cottin V, Flaherty KR, Hansell DM, Inoue Y, Kim DS, Kolb M, Nicholson AG, Noble PW, Selman M, Taniguchi H, Brun M, Le MF, Girard M, Stowasser S, SchlenkerHerceg R, Disse B, Collard HR. Efficacy and Safety of Nintedanib in Idiopathic Pulmonary Fibrosis. N Engl J Med. 2014. https://doi.org/10.1056/ NEJMoa1402584.

38. Wollin L, Wex E, Pautsch A, Schnapp G, Hostettler KE, Stowasser S, Kolb M. Mode of action of nintedanib in the treatment of idiopathic pulmonary fibrosis. Eur Respir J. 2015;45:1434-45. https://doi.org/10. 1183/09031936.00174914.

39. Cahill KN, Katz HR, Cui J, Lai J, Kazani S, Crosby-Thompson A, Garofalo D, Castro M, Jarjour N, DiMango E, Erzurum S, Trevor JL, Shenoy K, Chinchilli VM, Wechsler ME, Laidlaw TM, Boyce JA, Israel E. KIT inhibition by Imatinib in patients with severe refractory asthma. N Engl J Med. 2017;376:1911-20. https://doi.org/10.1056/NEJMoa1613125.

40. Humbert M, De BF, Garcia G, Prud'homme A, Leroyer C, Magnan A, Tunonde-Lara JM, Pison C, Aubier M, Charpin D, Vachier I, Purohit A, Gineste P, Bader T, Moussy A, Hermine O, Chanez P. Masitinib, a c-kit/PDGF receptor tyrosine kinase inhibitor, improves disease control in severe corticosteroiddependent asthmatics. Allergy. 2009;64:1194-201. ALL2122. https://doi.org/ 10.1111/j.1398-9995.2009.02122.x.

41. Back M, Walch L, Norel X, Gascard J, Mazmanian G, Brink C. Modulation of vascular tone and reactivity by nitric oxide in porcine pulmonary arteries and veins. Acta Physiol Scand. 2002;174:9-15.

42. Bonnet S, Archer SL. Potassium channel diversity in the pulmonary arteries and pulmonary veins: implications for regulation of the pulmonary vasculature in health and during pulmonary hypertension. Pharmacol Ther. 2007;115:56-69. S0163-7258(07)00076-9. https://doi.org/10.1016/j. pharmthera.2007.03.014.

43. Gao Y, Zhou H, Raj JU. Heterogeneity in role of endothelium-derived $\mathrm{NO}$ in pulmonary arteries and veins of full-term fetal lambs. Am J Physiol. 1995; 268:H1586-92. https://doi.org/10.1152/ajpheart.1995.268.4.H1586.

44. Norel X, Walch L, Gascard JP, de Montpreville V, Brink C. Prostacyclin release and receptor activation: differential control of human pulmonary venous and arterial tone. Br J Pharmacol. 2004;142:788-96. https://doi.org/10.1038/ sj.bjp.0705843.

45. Rieg $A D$, Rossaint $R$, Verjans $E$, Maihöfer NA, Uhlig S, Martin C. Levosimendan relaxes pulmonary arteries and veins in precision-cut lung slices - The role of KATP-channels, CAMP and CGMP. PLOS ONE. 2013;8(6): e66195. https://doi.org/10.1371/journal.pone.0066195.

46. Rieg AD, Rossaint R, Uhlig S, Martin C. Cardiovascular agents affect the tone of pulmonary arteries and veins in precision-cut lung slices. PLoS One. 2011; 6:e29698. https://doi.org/10.1371/journal.pone.0029698 PONE-D-11-15270.

47. Townsley MI. Structure and composition of pulmonary arteries, capillaries, and veins. Compr Physiol. 2012;2:675-709. https://doi.org/10.1002/cphy.c100081.

48. Giaid A, Yanagisawa M, Langleben D, Michel RP, Levy R, Shennib H, Kimura S, Masaki T, Duguid WP, Stewart DJ. Expression of endothelin-1 in the lungs of patients with pulmonary hypertension. N Engl J Med. 1993;328:1732-9. https://doi.org/10.1056/NEJM199306173282402. 
49. Schneider MP, Boesen El, Pollock DM. Contrasting actions of endothelin ET(a) and ET(B) receptors in cardiovascular disease. Annu Rev Pharmaco Toxicol. 2007:47:731-59.

50. Michelakis ED, Weir EK, Wu X, Nsair A, Waite R, Hashimoto K, Puttagunta L, Knaus HG, Archer SL. Potassium channels regulate tone in rat pulmonary veins. Am J Physiol Lung Cell Mol Physiol. 2001;280:L1138-47.

51. Manley PW, Stiefl N, Cowan-Jacob SW, Kaufman S, Mestan J, Wartmann M, Wiesmann M, Woodman R, Gallagher N. Structural resemblances and comparisons of the relative pharmacological properties of imatinib and nilotinib. Bioorg Med Chem. 2010;18:6977-86. S0968-0896(10)00771-6. https://doi.org/10.1016/j.bmc.2010.08.026.

52. Huang DY, Chao Y, Tai MH, Yu YH, Lin WW. STI571 reduces TRAIL-induced apoptosis in colon cancer cells: c-Abl activation by the death receptor leads to stress kinase-dependent cell death. J biomed Sci. 2012;19:35. https://doi. org/10.1186/1423-0127-19-35.

53. Karuppagounder SS, Brahmachari S, Lee Y, Dawson VL, Dawson TM, Ko HS The c-Abl inhibitor, nilotinib, protects dopaminergic neurons in a preclinical animal model of Parkinson's disease. Sci rep. 2014;4:4874. https://doi.org/10. 1038/srep04874

54. Udden SM, Morita-Fujimura Y, Satake M, Ikawa S. C-ABL tyrosine kinase modulates p53-dependent p21 induction and ensuing cell fate decision in response to DNA damage. Cell Signal. 2014;26:444-52. S08986568(13)00316-1. https://doi.org/10.1016/j.cellsig.2013.10.005.

55. Tang DD, Tan J. Role of Crk-associated substrate in the regulation of vascular smooth muscle contraction. Hypertension. 2003;42:858-63. https:// doi.org/10.1161/01.HYP.0000085333.76141.33.

56. Tang DD. Critical role of actin-associated proteins in smooth muscle contraction, cell proliferation, airway hyperresponsiveness and airway remodeling. Respir Res. 2015;16:134. https://doi.org/10.1186/s12931 015-0296-1.

57. Dubey DK, Chaubey KA, Parveen A, Ohja PR. Comparative study of inhibition of drug potencies of c-Abl human kinase inhibitors: a computational and molecular docking study. J Biophys Struct Biol. 2010;2:47-54.

58. Nelson MT, Quayle JM. Physiological roles and properties of potassium channels in arterial smooth muscle. Am J Phys. 1995;268:C799-822.

59. Ko EA, Han J, Jung ID, Park WS. Physiological roles of K+ channels in vascular smooth muscle cells. J Smooth Muscle Res. 2008:44:65-81.

60. Gur S, Sikka SC, Abdel-Mageed AB, Elmageed ZY, Rezk B, Pankey E, Kadowitz PJ, Hellstrom WJ. Imatinib Mesylate (Gleevec) Induces Human Corpus Cavernosum Relaxation by Inhibiting Receptor Tyrosine Kinases (RTKs): Identification of New RTK Targets. Urology. S0090-4295(13)00507-4. 2013. https://doi.org/10.1016/j.urology.2013.04.030.

61. Ozgur-Akdemir A, Demirturk K, Karabakan M, Volkan-Oztekin C, Abdulkadir NA, Cetinkaya M, Gur S, Hellstrom WJ. Imatinib mesylate (Gleevec) as protein-tyrosine kinase inhibitor elicits smooth muscle relaxation in isolated human prostatic tissue. Urology. 2011;78:968-6. S0090-4295(11)00688-1. https://doi.org/10.1016/j.urology.2011.06.033.

62. Puetz S, Lubomirov LT, Pfitzer G. Regulation of smooth muscle contraction by small GTPases. Physiology (Bethesda). 2009;24:342-56. https://doi.org/10. 1152/physiol.00023.2009.

63. Puetz $S$, Schroeter MM, Piechura $H$, Reimann L, Hunger MS, Lubomirov LT, Metzler D, Warscheid B, Pfitzer G. New insights into myosin phosphorylation during cyclic nucleotide-mediated smooth muscle relaxation. J Muscle Res Cell Motil. 2012;33:471-83. https://doi.org/10. 1007/s10974-012-9306-9.

64. Tang DD, Anfinogenova Y. Physiologic properties and regulation of the actin cytoskeleton in vascular smooth muscle. J Cardiovasc Pharmacol Ther. 2008;13:130-40. https://doi.org/10.1177/1074248407313737.

65. Morgado M, Cairrao E, Santos-Silva AJ, Verde I. Cyclic nucleotidedependent relaxation pathways in vascular smooth muscle. Cell Mol Life Sci. 2012;69:247-66.

66. Hughes AD. Increase in tone and intracellular Ca2+ in rabbit isolated ear artery by platelet-derived growth factor. Br J Pharmacol. 1995;114:138-42.

67. Sachinidis A, Locher R, Vetter W, Tatje D, Hoppe J. Different effects of platelet-derived growth factor isoforms on rat vascular smooth muscle cells. J Biol Chem. 1990;265:10238-43.

68. Sachinidis A, Locher R, Hoppe J, Vetter W. The platelet-derived growth factor isomers, PDGF-AA, PDGF-AB and PDGF-BB, induce contraction of vascular smooth muscle cells by different intracellular mechanisms. FEBS Lett. 1990;275:95-8 0014-5793(90)81447-V.
69. Vorkapic E, Dugic E, Vikingsson S, Roy J, Mayranpaa Ml, Eriksson P, Wagsater D. Imatinib treatment attenuates growth and inflammation of angiotensin II induced abdominal aortic aneurysm. Atherosclerosis. 2016;249:101-9. S00219150(16)30137-X. https://doi.org/10.1016/j.atherosclerosis.2016.04.006.

\section{Publisher's Note}

Springer Nature remains neutral with regard to jurisdictional claims in published maps and institutional affiliations.
Ready to submit your research? Choose BMC and benefit from:

- fast, convenient online submission

- thorough peer review by experienced researchers in your field

- rapid publication on acceptance

- support for research data, including large and complex data types

- gold Open Access which fosters wider collaboration and increased citations

- maximum visibility for your research: over $100 \mathrm{M}$ website views per year

At BMC, research is always in progress.

Learn more biomedcentral.com/submissions 